\title{
Effect of commercial mannoproteins on wine colour and tannins stability
}

\author{
A. Rodrigues ${ }^{\text {a,b }}$, J.M. Ricardo-Da-Silva ${ }^{\mathrm{a}, *},{\text { C. } \text { Lucas }^{\mathrm{b}} \text {, O. Laureano }}^{\mathrm{a}}$ \\ ${ }^{a}$ Universidade Técnica de Lisboa, Instituto Superior de Agronomia, Laboratório Ferreira Lapa (Sector de Enologia), 1349-017 Lisboa, Portugal \\ ${ }^{\mathrm{b}}$ Dão Sul - Sociedade Vitivinícola, S.A., Quinta das Sarzedas, 3430-909 Carregal do Sal, Portugal
}

\section{A R T I C L E I N F O}

\section{Article history:}

Received 25 March 2011

Received in revised form 2 July 2011

Accepted 19 September 2011

Available online 25 September 2011

\section{Keywords:}

Red wine

Mannoproteins

Anthocyanins

Proanthocyanidins

Polyphenols

Polysaccharides

\begin{abstract}
A B S T R A C T
Commercial oenological products containing mannoproteins have the purpose of preventing tartrate salts precipitation or achieving wines with a better mouth-feeling. The evaluation of the influence of three commercial mannoproteins on colour and tannin stability of three different red wines (two from Touriga Nacional and one from Alfrocheiro and Aragonês varieties) was studied. The evolution of colour through time was similar for all modalities, resulting in an increase of polymeric pigments and colour hue and a decrease of other parameters, suggesting that there was no influence of commercial mannoproteins on colour stability. The tannin profile evolution showed a possible stabilizing effect of one of the commercial products for tannins with an mDP between 8 and 14. It is possible that the commercial mannoproteins used in this work have some influence on the tannin aggregation evolution, contributing to the delay of tannin polymerisation in red wines.
\end{abstract}

(c) 2011 Elsevier Ltd. All rights reserved.

\section{Introduction}

Mannoproteins are one of the major polysaccharide groups present in wine (Feuillat, 2003), having their origin in the Saccharomyces cerevisiae yeast cell walls. Gonçalves, Heyraud, Pinho, and Rinaudo (2002) found that $32.2 \%$ of the total polysaccharides content of white wine corresponded to mannoproteins. These polysaccharides are glycoproteins and according to Klis, Mol, Hellingwerf, and Brul (2002) they represent $35-40 \%$ of the S. cerevisiae yeast cell wall. Mannoproteins are highly glycosylated and they are located on the cell wall external layer, where they are covalently linked to an amorphous matrix of $\beta-1,3$-glucans. Mannoproteins can be present in a wide range of molecular weights in wines that can vary between 5 and $400 \mathrm{kDa}$ according to Doco, Vuchot, Cheynier, and Moutounet (2003) and even 800 kDa (Saulnier, Mercereau, \& Vezinhet, 1991). Mannoproteins are composed by $10-20 \%$ of protein and about $80 \%$ of D-mannose associated to residues of D-glucose and $\mathrm{N}$ acetylglucosamine. The release of mannoproteins to wine can occur in two different processes: release during alcoholic fermentation in the yeast growing phase and release after yeast autolysis by the action of the exogenous $\beta-1,3$-glucanase enzyme on the yeast cell walls (Feuillat, 2003). These last mannoproteins are similar to those released during fermentation but they have less protein content (Saulnier et al., 1991).

Mannoproteins are known for several important properties in wines. They have the ability to adsorb ochratoxin A (Baptista

\footnotetext{
* Corresponding author. Tel.: +351 213653 542; fax: +351 213653200 .

E-mail address: jricardosil@isa.utl.pt (J.M. Ricardo-Da-Silva).
}

et al., 2004); to enhance malolactic bacteria growth (GuillouxBenatier, Guerreau, \& Feuillat, 1995); to inhibit tartaric salts crystallisation (Moine-Ledoux \& Dubourdieu, 2002); to prevent protein haziness (Waters, Pellerin, \& Brillouet, 1994); to enhance and interact with some wine aromas (Chalier, Angot, Delteil, Doco, \& Gunata, 2007); to promote flocculation and yeast autolysis in sparkling wines (Nunez, Carrascosa, González, Polo, \& MartinezRodriguez, 2006).

The interaction between mannoproteins and wine phenolic compounds is a subject of great interest as some studies show the possible impact on colour stability (Escot, Feuillat, Dulau, \& Charpentier, 2001; Poncet-Legrand, Doco, Williams, \& Vernhet, 2007; Riou, Vernhet, Doco, \& Moutounet, 2002; Vasserot, Caillet, \& Maujean, 1997) and an improvement in the sensory characteristics, namely the reduction of red wine astringency (Guadalupe, Martínez, \& Ayestarán, 2010; Guadalupe, Palacios, \& Ayestarán, 2007). Red wine colour is mainly due to the presence of anthocyanins existing in the coloured forms at wine $\mathrm{pH}$, when wines are young, and to the formation of more stable polymeric pigments with ageing of the wine, namely by condensation of flavanoid units (Dallas, Ricardo da Silva, \& Laureano, 1996; Somers, 1971). Proanthocyanidins or condensed tannins are polymeric flavanoids, resulting from the condensation between flavan-3-ol units, and are related with wine astringency, bitterness and colour. Wine tannins are composed by monomer units of (+)-catechin and (-)epicatechin, (procyanidins) and/or monomer units of $(-)$-epigallocatechin (prodelphinidins), sometimes esterified by gallic acid (Fulcrand, Remy, Souquet, Cheynier, \& Moutounet, 1999; Haslam, 1980; Ricardo da Silva, Rosec, Bourzeix, \& Heredia, 1990). 
The interaction between colour compounds and tannins with mannoproteins is extremely important as it can influence colour stability and improve sensory qualities. Some works (Guadalupe \& Ayestarán, 2008; Guadalupe et al., 2007, 2010) showed that there was no positive interaction between mannoproteins and colour compounds and that the interaction between mannoproteins and tannins resulted in a decrease of wine tannin content, suggesting the precipitation of tannin and mannoprotein aggregates and a decrease in astringency with an increase of the wine sweetness and roundness. There are several oenological products in the market that contain mannoproteins in their composition with the aim of preventing wine potassium tartrate precipitation (Moine-Ledoux, Perrin, Paladin, \& Dubourdieu, 1997), and achieve wines with a better mouth-feeling (Guadalupe \& Ayestarán, 2008).

Considering the fact that colour stabilisation is one of the most important objectives for some wine producers it is important to understand with which tools the winemaker can work with in order to assure the quality and evolution of the wines. Bearing this in mind, the aim of this work was to evaluate the influence of three commercial mannoproteins enriched preparations in the colour stability and tannin evolution of three different red wines (two from Touriga Nacional and other from Alfrocheiro and Aragonês (sin. Tempranillo) grapevine varieties).

\section{Materials and methods}

\subsection{Chemicals}

All chemicals used were of analytical reagent grade. All solvents were of HPLC grade. (+)-Catechin, (-)-epicatechin, (-)-epicatechin-3-O-gallate and (-)-epigallocatechin were purchased from Extrasynthese (Genay, France). Toluene- $\alpha$-thiol (phenylmethanethiol) was purchased from Fluka (Buchs, Switzerland).

\subsection{Wines}

Grapes from Touriga Nacional, Aragonês and Alfrocheiro were harvested and vinified at Dão Sul winery (Dão Region, Portugal) in order to prepare three different red wines: wine A: Touriga Nacional variety harvested in 2007 (9000 kg); wine B: Alfrocheiro + Aragonês varieties harvested in 2007 (9000 kg); wine C: Touriga Nacional variety harvested in 2009 (9000 kg). The grapes were de-stemmed and crushed into a stainless steel vessel and a preparation of commercial maceration enzymes was added to each vessel. After $24 \mathrm{~h}$ of cold pre-fermentative maceration at $15^{\circ} \mathrm{C}$, the musts were inoculated with a commercial activated $S$. cerevisiae preparation. The alcoholic fermentation occurred for ten days at $20-25^{\circ} \mathrm{C}$. After the beginning of the alcoholic fermentation, the musts were punched down for 20 min every three hours, and they were submitted to a rack and return program for half an hour every day, until the end of alcoholic fermentation. After the end of alcoholic fermentation, the free-run wines were transferred to another stainless steel vessel in order to perform malolactic fermentation. The three wines were analysed for ethanol content, $\mathrm{pH}$, volatile acidity, titrable acidity and free and total $\mathrm{SO}_{2}$ according to the Organisation International de la Vigne et du Vin official methods (OIV, 2006). The wines chemical parameters were the following: wine A: alcohol content $13.3 \% \mathrm{v} / \mathrm{v}$, titrable acidity $5.3 \mathrm{~g} / \mathrm{l}$ expressed in tartaric acid, volatile acidity $0.5 \mathrm{~g} / \mathrm{l}$ expressed in acetic acid, $\mathrm{pH}$ $3.82,21 \mathrm{mg} / \mathrm{l}$ of free $\mathrm{SO}_{2}, 40 \mathrm{mg} / \mathrm{l}$ of total $\mathrm{SO}_{2}$; wine B: alcohol content $13.6 \% \mathrm{v} / \mathrm{v}$, titrable acidity $5.5 \mathrm{~g} / \mathrm{l}$ expressed in tartaric acid, volatile acidity $0.5 \mathrm{~g} / \mathrm{l}$ expressed in acetic acid, $\mathrm{pH} 3.82,12 \mathrm{mg} / \mathrm{l}$ of free $\mathrm{SO}_{2}, 27 \mathrm{mg} / \mathrm{l}$ of total $\mathrm{SO}_{2}$; wine C: alcohol content $13.6 \% \mathrm{v} / \mathrm{v}$, titrable acidity $7.8 \mathrm{~g} / \mathrm{l}$ expressed in tartaric acid, volatile acidity $0.3 \mathrm{~g} / \mathrm{l}$ expressed in acetic acid, $\mathrm{pH} 4.05,15 \mathrm{mg} / \mathrm{l}$ of free $\mathrm{SO}_{2}, 32 \mathrm{mg} / \mathrm{l}$ of total $\mathrm{SO}_{2}$. At the end of malolactic fermentation, two different experiments were prepared.

\subsection{Mannoprotein commercial preparations trials in red wines}

Two different commercial preparations containing yeast mannoproteins (MP1 and MP2) were added to wines A and B in concentrations of $0.2 \mathrm{~g} / \mathrm{l}$ (C1) and $0.4 \mathrm{~g} / \mathrm{l}$ (C2) after malolactic fermentation according to the manufacturer's indications, followed by bottling of the resulting wines. T samples refer to wine with no addition of commercial mannoprotein preparations. The bottled wines were kept at winery temperatures $\left(20 \pm 3^{\circ} \mathrm{C}\right)$ for twentyone months. Samples of each wine were analysed for their colour characterisation and proanthocyanidins composition at $0,28,91$, 122, 164, 256 and 644 days. Two different commercial preparations containing yeast mannoproteins (MP2 and MP3) were added to wine $C$ in concentration of $0.3 \mathrm{~g} / \mathrm{l}$ after malolactic fermentation according to the manufacturer's indications. The wines were kept in amber flasks, at $35^{\circ} \mathrm{C}$, for sixty days. Samples of each wine were analysed for their colour characterisation and proanthocyanidins composition according to their degree of polymerisation at 0,6 , $13,19,26,47$ and 60 days.

\subsection{Colour characterisation}

In order to characterise the wine colour compounds it was used the spectrophotometrical method described by Somers and Evans (1977). The wines were centrifuged for $10 \mathrm{~min}$ at 3.500 r.p.m. and the absorbances were measured using a Unicam UV-Vis UV4 spectrophotometer (Unicam, Cambridge, UK).

\subsection{Proanthocyanidins analysis}

\subsubsection{Isolation of oligomeric and polymeric proanthocyanidins}

The isolation of wine proanthocyanidins was made according to the methods described by Sun, Leandro, Ricardo da Silva, and Spranger (1998) and Labarbe, Cheynier, Brossaud, Souquet, and Moutounet (1999). Four millilitres of wine were injected onto a Toyopearl TSK HW-40F (Tosoh Corp., Tokyo, Japan) packed column $(100 \times 10 \mathrm{~mm})$ and first washed with a solution of ethanol:water:TFA (55:45:0.05 v/v/v) in order to remove small molecules and flavan-3-ols. The wine oligomeric and polymeric proanthocyanidins were eluted with a solution of acetone:water $(40: 60 \mathrm{v} / \mathrm{v})$. After evaporation of the tannin fraction at $30^{\circ} \mathrm{C}$ under vacuum, the proanthocyanidins were resuspended in $1 \mathrm{ml}$ of methanol to be used in further analysis.

\subsubsection{Fractionation of wine proanthocyanidins according to their} degree of polymerisation using a sequential dissolving procedure on an inert glass powder column

The wine $C$ proanthocyanidins were separated according to their degree of polymerisation as described by Labarbe et al. (1999) during the experiment time. One millilitre of proanthocyanidins methanol solution was precipitated by chloroform on the top of a glass powder column $(50 \times 10 \mathrm{~mm})$. The elution gradient (chloroform/ methanol) was applied as following: FI - 75:25 (v/v); FII - 70:30 (v/v); FIII - 65:35 (v/v); FIV - 60:40 (v/v); FV - 55:45 (v/v); FVI 50:50 (v/v); FVII - 45:55 (v/v); FVIII - 0:100 (v/v). The eight fractions were analysed by HPLC after thiolysis in order to determine their structural characteristics.

\subsubsection{Characterisation of wine proanthocyanidins by acid-catalysed} depolymerisation in the presence of toluene- $\alpha$-thiol followed by reversed-phase HPLC analysis

The proanthocyanidins were submitted to depolymerisation in the presence of toluene- $\alpha$-thiol in an acidic medium as described 
by Monagas, Gómez-Cordovés, Bartolomé, Laureano, and Ricardoda-Silva (2003). $100 \mu$ l of toluene- $\alpha$-thiol $5 \%$ in methanol $0.2 \mathrm{M}$ $\mathrm{HCl}$ were added to $100 \mu \mathrm{l}$ of proanthocyanidins solution in a hermetically sealed glass tube. The mixture was warmed up to $55^{\circ} \mathrm{C}$ on a water bath for $7 \mathrm{~min}$. Ten microlitres of the prepared solution were immediately injected in a HPLC system equipped with a Merck Hitachi Lachrom L-7100 Pump (Merck Hitachi, Tokyo, Japan), followed by a Phenomenex Gemini C18 110 A $150 \times 3.0 \mathrm{~mm}$ column (Phenomenex, California, USA) and a UV/ Vis Waters 2487 Dual Wavelength detector (Waters, Massachusetts, USA), in the following elution conditions: $0.8 \mathrm{ml} / \mathrm{min}$ flow with a linear gradient of $15-75 \%$ of a solution of acetonitrile/ water/formic acid (80:18:2, v/v/v) in a solution of water/formic acid $(98: 2, v / v)$, in an $18 \mathrm{~min}$ run. The detection was monitored at 280 and $320 \mathrm{~nm}$. The amounts of monomers and of toluene- $\alpha-$ thiol adducts released were calculated from the areas of the chromatographic peaks at $280 \mathrm{~nm}$ by comparison with calibration curves (Rigaud, Perez-Ilzarbe, Ricardo da Silva, \& Cheynier, 1991).

\subsection{Mannoprotein characterisation}

A centrifuged solution of commercial mannoproteins at $1 \mathrm{~g} / \mathrm{l}$ was injected onto a concanavalin-A Sepharose 4B (GE Healthcare Bio-Sciences, Uppsala, Sweden) packed column $(100 \times 10 \mathrm{~mm})$, and eluted with a sodium acetate- $\mathrm{HCl} 50 \mathrm{mM} \mathrm{pH} 5.6, \mathrm{NaCl}$ $150 \mathrm{mM}, \mathrm{CaCl}_{2} 1 \mathrm{mM}, \mathrm{MgCl}_{2} 1 \mathrm{mM}$ and $\mathrm{MnCl}_{2} 1 \mathrm{mM}$ buffer solution at $0.8 \mathrm{ml} / \mathrm{min}$; elution was monitored by a refraction index and a $254 \mathrm{~nm}$ wavelength detectors as described by Gonçalves et al. (2002). The bound fraction was eluted with the same buffer solution containing methyl $\alpha$-D-mannopyranoside, $500 \mathrm{mM}$. The bound fraction was dialysed against water for 7 days, at $4{ }^{\circ} \mathrm{C}$. After freeze drying of the bound fraction, the sample $(1 \mathrm{~g} / \mathrm{l})$ was injected onto a FPLC system equipped with a Pharmacia LKB Pump P-500, a 12HR 10/30 FPLC size-exclusion column (GE Healthcare Bio-Sciences, Uppsala, Sweden), eluted with an ammonium acetate $0.3 \mathrm{M}$ buffer solution at $0.3 \mathrm{ml} / \mathrm{min}$ and monitored by a Perkin-Elmer LC-30 RI refractive index detector (Perkin-Elmer, Massachusetts, USA) modified with a LED (light-emitting diode) light source (Cromolab, Queijas, Portugal) and a Knauer WellChrom Spectro-Photometer K-2501 wavelength detector (Knauer, Berlin, Germany) at $254 \mathrm{~nm}$. Calibration of the system was performed with Shodex P-82 pullulan standards (Showa Denko K.K., Kanagawa, Japan).

The carbohydrate composition was determined by gas chromatography after derivatization of the samples into their alditol acetates according to Albersheim, Nevis, English, and Karr (1967). Hundred microlitres of a $\mu$-inositol solution $(1 \mathrm{mg} / \mathrm{ml})$ and $1 \mathrm{ml}$ of trifluoroacetic acid $2 \mathrm{M}$ were added to $1 \mathrm{ml}$ of polysaccharides solution $(1 \mathrm{mg} / \mathrm{ml})$. After hydrolysis at $120^{\circ} \mathrm{C}$, for $75 \mathrm{~min}$, the mixture was washed with $5 \mathrm{ml}$ of water and dried. $500 \mu \mathrm{l}$ of a saturated sodium borohydride solution in ammonia were added and the mixture reacted for two hours at room temperature. The reaction was stopped by adding some drops of glacial acetic acid and the mixture was washed with $5 \mathrm{ml}$ of a solution of $1 \% \mathrm{HCl}$ in methanol and dried. One hundred and fifty microlitres of pyridine and $150 \mu \mathrm{l}$ of acetic anhydride were added to the mixture and left to react for $12 \mathrm{~h}$ at room temperature. The reaction was stopped by adding a drop of water in an ice bath. The mixture was washed with $5 \mathrm{ml}$ water, followed by $1 \mathrm{ml}$ of ethanol, and then dried. The alditol acetates were extracted to $200 \mu \mathrm{l}$ of chloroform and were quantified on a CE Instruments GC 8000 Top gas chromatographer (Thermo Fisher Scientific, Milan, Italy) with a capillary column Zebron ZB-Wax $1060 \times 0.25 \mathrm{~mm}, 0.25 \mu \mathrm{m}$ film (Phenomenex, California, US(A) and a FID detector. The column temperature was initially set at $220^{\circ} \mathrm{C}$ for $4 \mathrm{~min}$ and was raised to $235^{\circ} \mathrm{C}$ at $10^{\circ} \mathrm{C} / \mathrm{min}$, maintaining this temperature for $5 \mathrm{~min}$. Hydrogen was used as
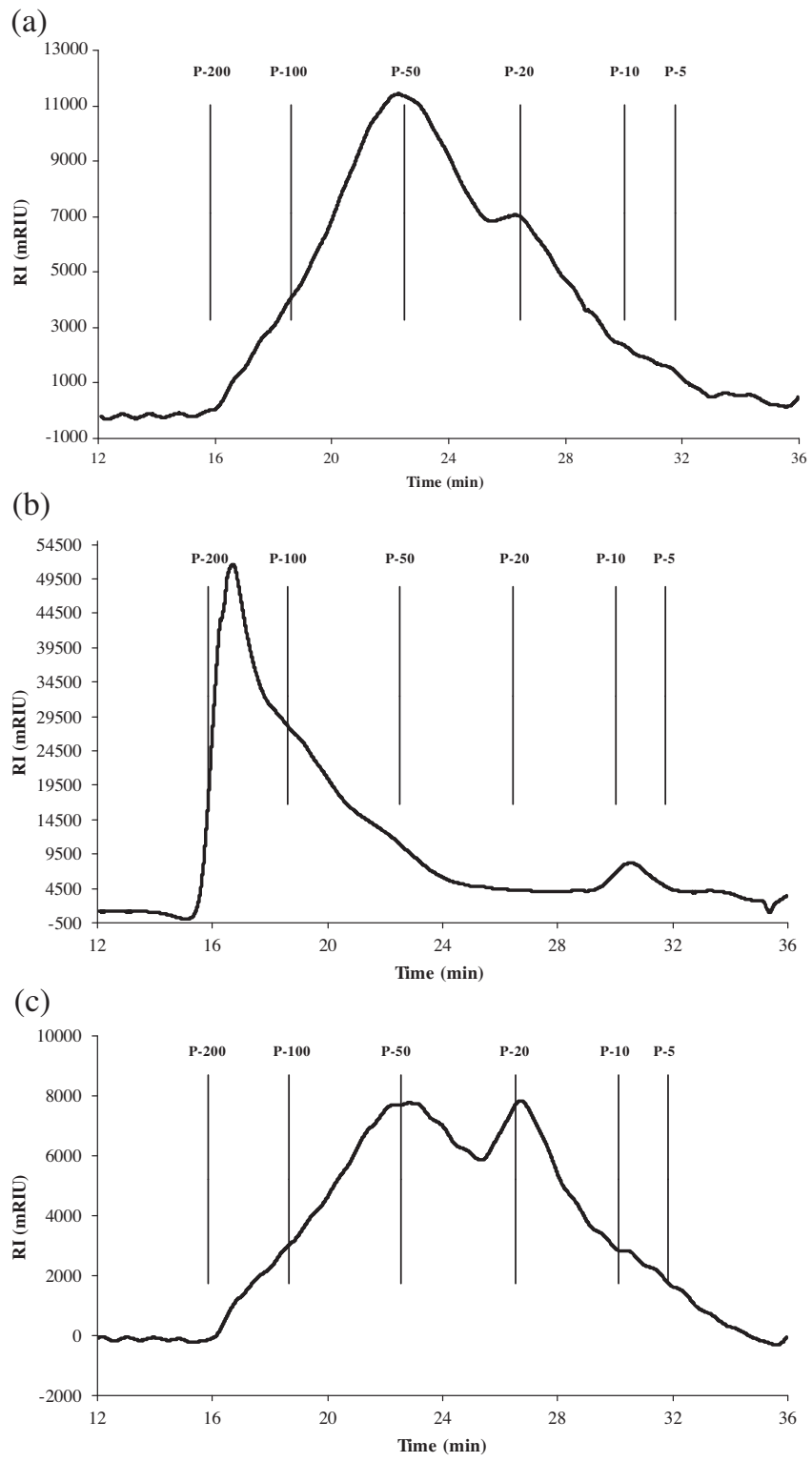

Fig. 1. Molecular weight distribution of the concanavalin-A column retained fraction of the commercial mannoproteins by FPLC on a Superose 12HR column, with the elution of the pullulan standards - (a) MP1, (b) MP2, and (c) MP3.

carrier gas at $1 \mathrm{ml} / \mathrm{min}$. $\mu$-Inositol was used as the internal standard, sugar quantification was carried out after determination of each sugar response factor using pure sugars as standards.

The total protein content was determined as described by Lowry, Roserbrough, Farr, and Randall (1951) using bovine serum albumin fraction V (Sigma-Aldrich, Missouri, USA) for the calibration curve.

The total polysaccharides content was determined by the phenol-sulphuric method as described by Dubois, Gilles, Hamilton, Rebers, and Smith (1956) using glucose (Panreac, Barcelona, Spain) for the calibration curve.

\section{Results and discussion}

\subsection{Characterisation of the commercial mannoproteins}

After purification on concanavalin-A, the retained fractions of the three commercial mannoproteins used were characterised 
with regards to their total polysaccharide content, total proteins content and their glycosyl residue composition. MP1 was composed of $11.5 \%$ protein and $85.2 \%$ of polysaccharides, mannose being the main sugar (99.3\%), followed by glucose (0.7\%). MP2 was composed of $4.3 \%$ protein and $83.1 \%$ polysaccharides, and mannose was the only residual sugar detected. MP3 was composed of $0.8 \%$ protein and $67.3 \%$ polysaccharides, with $99.8 \%$ mannose and $0.2 \%$ glucose. The molecular weight distribution of the concanavalin-A retained fractions for the three commercial mannoproteins is shown in Fig. 1. MP1 showed two different peaks, corresponding to two fractions with an average molecular weight around 43 and $17 \mathrm{kDa}$. MP2 also presented two different peaks with an average molecular weight around 164 and $8 \mathrm{kDa}$, as well as MP3, with two peaks corresponding to average molecular weights around 44 and $19 \mathrm{kDa}$.

\subsection{Effect of commercial mannoproteins addition on colour compounds evolution}

\subsubsection{Wines $A$ and $B$}

Table 1 shows the evolution of colour parameters at days 0,164 and 644. Both studied wines had the same evolution for these parameters. The total polyphenols (TP) represents the absorbance at $280 \mathrm{~nm}$. All wines presented the same evolution of TP, slightly decreasing through time. The colour intensity $(\mathrm{CI})$ represents the sum of absorbances at 420,520 and $620 \mathrm{~nm}$. In all the experiments of wines A and B CI tended to decrease with time for all samples in the same way, as a result of the polymerisation and precipitation of colour compounds. It seemed that the wines with no commercial mannoproteins addition (T sample) maintained the colour intensity slightly higher than the other samples. This difference ranged from 0.5 to 0.9 in wine A. Guadalupe and Ayestarán (2008) have suggested that mannoproteins can co-precipitate with stable colour but Escot et al. (2001) suggested that mannoproteins could prevent tannin and anthocyanins precipitation. The evolution of colour hue reinforces the fact that there was no stabilisation of colour compounds at $520 \mathrm{~nm}$, evolving to a higher absorbance at $420 \mathrm{~nm}$ for both wines. Polymeric pigments (PP) represent longer chain coloured compounds resulting from the condensation reactions between anthocyanins and flavanol units (Somers, 1971). PP tended to increase with time, with no important differences between samples, being slightly higher for the T sample. Coloured anthocyanins are the ones that at wine $\mathrm{pH}$ have a red colour, as defined by Somers and Evans (1977). They tended to decrease with time, resulting in wine browning that was in accordance with the results for IC and hue. As with the other parameters no significant differences were seen between samples. For the total anthocyanins (TA), the evolution was also similar for all samples, decreasing with time. At the end of the trail, on day 644, the T sample had less amount of TA in comparison with the other samples, showing a lower stabilisation of these compounds.

\subsubsection{Wine $C$}

The evolution of the colour parameters with time for the samples based on wine $C$ are represented in Fig. 2. The CI (Fig. 2a) decreased slightly at the beginning for MP2 and even more for the MP3 sample. Until the end of the experiment, both samples maintained a stable evolution through time. The T sample maintained a stable evolution until the 47 th day, increasing at the end of the experiment. For the colour hue (Fig. 2b), the evolution with time was very similar for all samples. The polymeric pigments (Fig. 2c) also increased with time, and at the end of the 60th day, the T sample presented higher values of PP. The total anthocyanins evolution had some differences between samples (Fig. 2d). The MP3 sample had an increase in these compounds at the beginning in contrast to MP2 and T, as well as a slower evolution. At the end of the experiment, the $\mathrm{T}$ sample had less anthocyanins than the MP2 and MP3 that behaved in the same way.

\subsection{Effect of commercial mannoproteins on proanthocyanidins evolution}

\subsubsection{Wines $A$ and $B$}

Both studied wines had similar trends for tannin parameters. Concerning wine A (Fig. 3a and b), the T sample had a slower decrease both on $\mathrm{mDP}$ and proanthocyanidins content (PA) with time, and MP1C1 had the fastest. The sample MP2C2 seemed to have some protective effect on tannins precipitation as it was the

\section{Table 1}

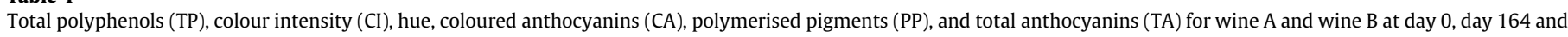
day 644.

\begin{tabular}{|c|c|c|c|c|c|c|c|c|c|c|c|}
\hline \multirow{3}{*}{$\begin{array}{l}\text { Wine } \\
\text { Sample }\end{array}$} & & \multirow[t]{3}{*}{$\mathrm{T}$} & \multicolumn{4}{|l|}{ A } & \multirow[t]{3}{*}{$\mathrm{T}$} & \multicolumn{4}{|l|}{ B } \\
\hline & & & \multicolumn{2}{|l|}{ MP1 } & \multicolumn{2}{|l|}{ MP2 } & & \multicolumn{2}{|l|}{ MP1 } & \multicolumn{2}{|l|}{ MP2 } \\
\hline & & & $\mathrm{C} 1$ & $\mathrm{C} 2$ & $\mathrm{C} 1$ & $\mathrm{C} 2$ & & $\mathrm{C} 1$ & $\mathrm{C} 2$ & $\mathrm{C} 1$ & $\mathrm{C} 2$ \\
\hline $\mathrm{TP}(\mathrm{AU})$ & $\begin{array}{l}0 \text { days } \\
164 \text { days } \\
644 \text { days }\end{array}$ & $\begin{array}{l}85.8 \pm 0.0 \\
73.2 \pm 0.0 \\
64.0 \pm 0.1\end{array}$ & $\begin{array}{l}85.8 \pm 0.0 \\
76.9 \pm 0.0 \\
67.8 \pm 0.0\end{array}$ & $\begin{array}{l}85.8 \pm 0.0 \\
77.4 \pm 0.0 \\
61.3 \pm 0.0\end{array}$ & $\begin{array}{l}85.8 \pm 0.0 \\
75.5 \pm 0.0 \\
63.2 \pm 0.0\end{array}$ & $\begin{array}{l}85.8 \pm 0.0 \\
78.0 \pm 0.0 \\
62.2 \pm 0.0\end{array}$ & $\begin{array}{l}79.4 \pm 0.0 \\
74.4 \pm 0.0 \\
65.3 \pm 0.0\end{array}$ & $\begin{array}{l}79.4 \pm 0.0 \\
72.0 \pm 0.0 \\
65.5 \pm 0.0\end{array}$ & $\begin{array}{l}79.4 \pm 0.0 \\
74.4 \pm 0.0 \\
69.9 \pm 0.0\end{array}$ & $\begin{array}{l}79.4 \pm 0.0 \\
71.2 \pm 0.0 \\
76.0 \pm 0.0\end{array}$ & $\begin{array}{l}79.4 \pm 0.0 \\
75.1 \pm 0.0 \\
68.7 \pm 0.1\end{array}$ \\
\hline $\mathrm{CI}(\mathrm{AU})$ & $\begin{array}{l}0 \text { days } \\
164 \text { days } \\
644 \text { days }\end{array}$ & $\begin{array}{l}19.0 \pm 0.0 \\
15.7 \pm 0.2 \\
14.7 \pm 0.0\end{array}$ & $\begin{array}{l}19.0 \pm 0.0 \\
16.5 \pm 0.1 \\
13.8 \pm 0.1\end{array}$ & $\begin{array}{l}19.0 \pm 0.0 \\
16.2 \pm 0.2 \\
13.9 \pm 0.1\end{array}$ & $\begin{array}{l}19.0 \pm 0.0 \\
15.8 \pm 0.0 \\
13.9 \pm 0.2\end{array}$ & $\begin{array}{l}19.0 \pm 0.0 \\
16.5 \pm 0.0 \\
14.3 \pm 0.2\end{array}$ & $\begin{array}{l}17.4 \pm 0.0 \\
17.0 \pm 0.0 \\
14.4 \pm 0.1\end{array}$ & $\begin{array}{l}17.4 \pm 0.0 \\
16.8 \pm 0.0 \\
14.4 \pm 0.1\end{array}$ & $\begin{array}{l}17.4 \pm 0.0 \\
16.4 \pm 0.0 \\
14.4 \pm 0.0\end{array}$ & $\begin{array}{l}17.4 \pm 0.0 \\
17.8 \pm 0.0 \\
14.9 \pm 0.1\end{array}$ & $\begin{array}{l}17.4 \pm 0.0 \\
16.3 \pm 0.1 \\
14.2 \pm 0.1\end{array}$ \\
\hline Hue (AU) & $\begin{array}{l}0 \text { days } \\
164 \text { days } \\
644 \text { days }\end{array}$ & $\begin{array}{l}0.53 \pm 0.00 \\
0.68 \pm 0.01 \\
0.77 \pm 0.00\end{array}$ & $\begin{array}{l}0.53 \pm 0.00 \\
0.67 \pm 0.00 \\
0.79 \pm 0.01\end{array}$ & $\begin{array}{l}0.53 \pm 0.00 \\
0.67 \pm 0.00 \\
0.77 \pm 0.00\end{array}$ & $\begin{array}{l}0.53 \pm 0.00 \\
0.69 \pm 0.00 \\
0.80 \pm 0.01\end{array}$ & $\begin{array}{l}0.53 \pm 0.00 \\
0.67 \pm 0.00 \\
0.76 \pm 0.00\end{array}$ & $\begin{array}{l}0.55 \pm 0.00 \\
0.62 \pm 0.00 \\
0.79 \pm 0.00\end{array}$ & $\begin{array}{l}0.55 \pm 0.00 \\
0.65 \pm 0.00 \\
0.79 \pm 0.00\end{array}$ & $\begin{array}{l}0.55 \pm 0.00 \\
0.62 \pm 0.00 \\
0.77 \pm 0.00\end{array}$ & $\begin{array}{l}0.55 \pm 0.00 \\
0.63 \pm 0.00 \\
0.78 \pm 0.00\end{array}$ & $\begin{array}{l}0.55 \pm 0.00 \\
0.66 \pm 0.00 \\
0.81 \pm 0.00\end{array}$ \\
\hline $\mathrm{PP}(\mathrm{mg} / \mathrm{L})$ & $\begin{array}{l}0 \text { days } \\
164 \text { days } \\
644 \text { days }\end{array}$ & $\begin{array}{l}63 \pm 0 \\
70 \pm 0 \\
83 \pm 1\end{array}$ & $\begin{array}{l}63 \pm 0 \\
72 \pm 0 \\
84 \pm 1\end{array}$ & $\begin{array}{l}63 \pm 0 \\
70 \pm 0 \\
80 \pm 1\end{array}$ & $\begin{array}{l}63 \pm 0 \\
69 \pm 0 \\
83 \pm 1\end{array}$ & $\begin{array}{l}63 \pm 0 \\
72 \pm 0 \\
80 \pm 1\end{array}$ & $\begin{array}{l}57 \pm 0 \\
66 \pm 0 \\
85 \pm 0\end{array}$ & $\begin{array}{l}57 \pm 0 \\
72 \pm 0 \\
84 \pm 0\end{array}$ & $\begin{array}{l}57 \pm 0 \\
63 \pm 0 \\
81 \pm 0\end{array}$ & $\begin{array}{l}57 \pm 0 \\
71 \pm 0 \\
82 \pm 0\end{array}$ & $\begin{array}{l}57 \pm 0 \\
70 \pm 0 \\
79 \pm 0\end{array}$ \\
\hline $\mathrm{CA}(\mathrm{mg} / \mathrm{L})$ & $\begin{array}{l}0 \text { days } \\
164 \text { days } \\
644 \text { days }\end{array}$ & $\begin{array}{r}154 \pm 0 \\
90 \pm 2 \\
60 \pm 1\end{array}$ & $\begin{array}{r}154 \pm 0 \\
97 \pm 1 \\
49 \pm 1\end{array}$ & $\begin{array}{r}154 \pm 0 \\
96 \pm 2 \\
55 \pm 0\end{array}$ & $\begin{array}{r}154 \pm 0 \\
91 \pm 0 \\
50 \pm 2\end{array}$ & $\begin{array}{r}154 \pm 0 \\
98 \pm 2 \\
60 \pm 0\end{array}$ & $\begin{array}{r}141 \pm 0 \\
116 \pm 1 \\
53 \pm 1\end{array}$ & $\begin{array}{r}141 \pm 0 \\
104 \pm 0 \\
54 \pm 1\end{array}$ & $\begin{array}{r}141 \pm 0 \\
111 \pm 1 \\
58 \pm 1\end{array}$ & $\begin{array}{r}141 \pm 0 \\
117 \pm 0 \\
61 \pm 0\end{array}$ & $\begin{array}{r}141 \pm 0 \\
100 \pm 1 \\
56 \pm 1\end{array}$ \\
\hline $\mathrm{TA}(\mathrm{mg} / \mathrm{L})$ & $\begin{array}{l}0 \text { days } \\
164 \text { days } \\
644 \text { days }\end{array}$ & $\begin{array}{l}715 \pm 1 \\
436 \pm 1 \\
104 \pm 0\end{array}$ & $\begin{array}{l}715 \pm 1 \\
439 \pm 1 \\
115 \pm 1\end{array}$ & $\begin{array}{l}715 \pm 1 \\
426 \pm 1 \\
131 \pm 1\end{array}$ & $\begin{array}{l}715 \pm 1 \\
474 \pm 1 \\
113 \pm 1\end{array}$ & $\begin{array}{l}715 \pm 1 \\
417 \pm 0 \\
132 \pm 1\end{array}$ & $\begin{array}{l}767 \pm 1 \\
442 \pm 1 \\
135 \pm 1\end{array}$ & $\begin{array}{l}767 \pm 1 \\
424 \pm 1 \\
141 \pm 1\end{array}$ & $\begin{array}{l}767 \pm 1 \\
434 \pm 1 \\
166 \pm 0\end{array}$ & $\begin{array}{l}767 \pm 1 \\
455 \pm 1 \\
183 \pm 1\end{array}$ & $\begin{array}{l}767 \pm 1 \\
464 \pm 1 \\
179 \pm 1\end{array}$ \\
\hline
\end{tabular}

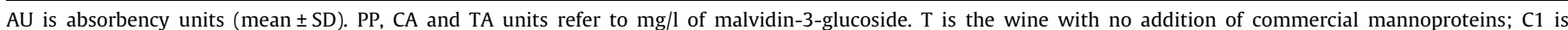
concentration of $0.2 \mathrm{~g} / \mathrm{L} ; \mathrm{C} 2$ is concentration of $0.4 \mathrm{~g} / \mathrm{L} ; \mathrm{MP} 1$ and MP2 are commercial yeast mannoproteins. 

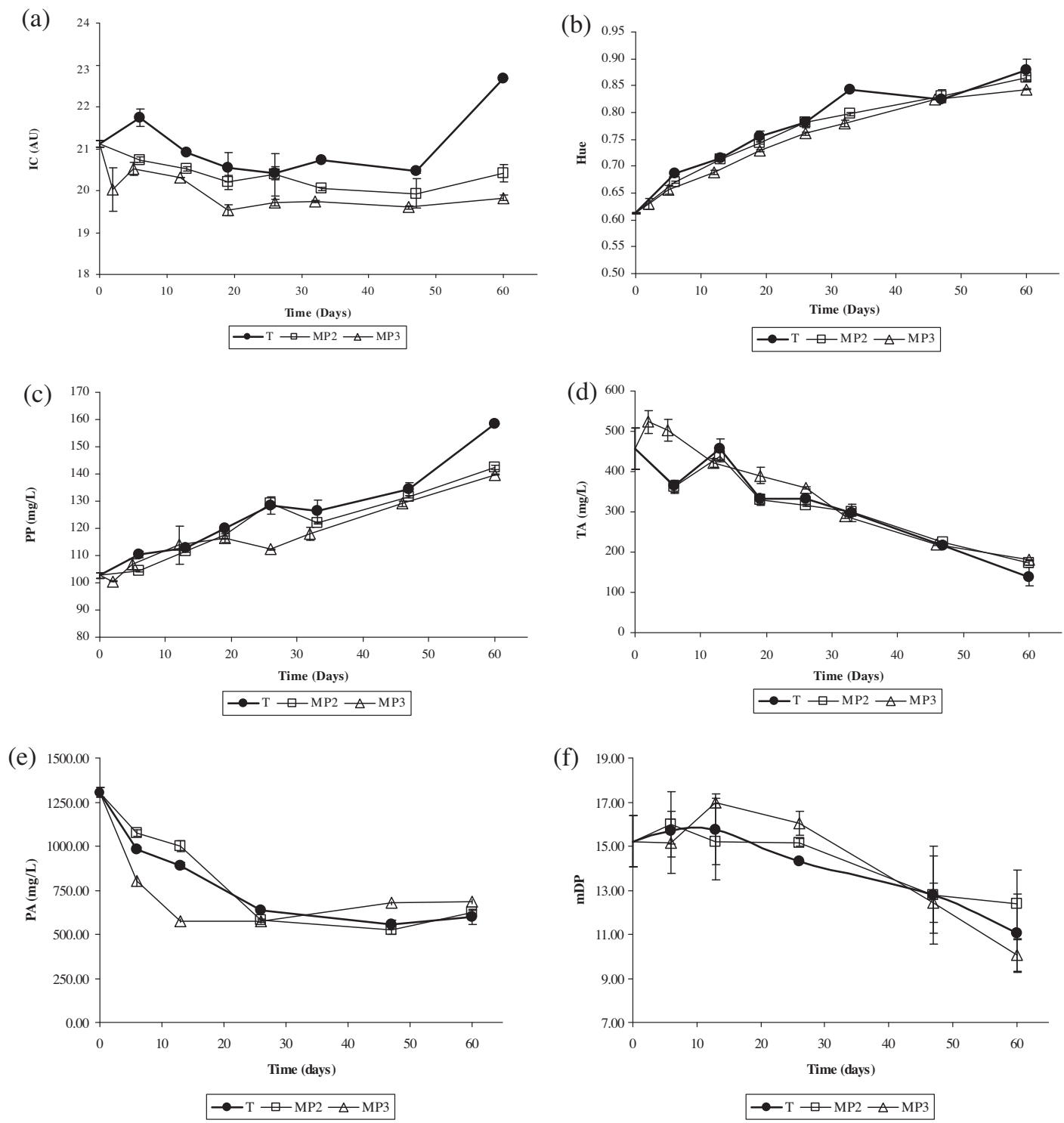

Fig. 2. (a) Colour intensity (CI), (b) hue, (c) polymeric pigments (PP), (d) total anthocyanins (TA), (e) total proanthocyanidins (PA), and (f) mDP evolutions of wine C.

one that showed the slowest rate of decrease until the end of the experiment. Referring to wine $\mathrm{B}$, the situation was similar, with a decrease of $\mathrm{mDP}$ and PA for all samples (Fig. $3 \mathrm{c}$ and $\mathrm{d}$ ). The MP1C2 sample seemed to have a slower decrease of mDP. The quantity of proanthocyanidins was slightly higher for the T sample after 164 days, than for the mannoprotein added samples. It is important to notice that the method used to achieve the concentration of proanthocyanidins on wine refers only to native tannins, resulting in a big decrease of these forms as they conjugate with anthocyanins directly, or with an ethanol bridge during wine ageing.

\subsubsection{Wine $C$}

In order to understand what was happening among the proanthocyanidins in the samples with added commercial mannoproteins, and as other authors already have reported the lack of a tannin stabilisation character of commercial mannoproteins on the wine polyphenolic and colour composition (Guadalupe \& Ayestarán, 2008; Guadalupe et al., 2007, 2010), it was important to verify if there was any influence by the commercial mannoproteins in the different proanthocyanidins polymer chains, according to their degree of polymerisation. For this, wine $\mathrm{C}$ was added with two different commercial mannoproteins, at the same concentration, and incubated at $35^{\circ} \mathrm{C}$ permanently for sixty days, in order to accelerate any polymerisation reactions that could occur between proanthocyanidins themselves and other wine compounds, namely with anthocyanins. Each sample was then divided into eight polymer fractions and submitted to thiolysis for galloylation and prodelphinidins percentage and estimation of their $\mathrm{mDP}$ and PA content.

Table 2 shows the evolution of galloylation and prodelphinidins percentage for global proanthocyanidins and for each mDP interval. Both galloylation and prodelphinidins percentage with time was constant, with no significant differences between samples. By evaluating the evolution of the total proanthocyanidins present in the wine (Fig. 2e), it was possible to conclude that at day 61 the quantity of tannins was slightly higher on MP3 sample than on T and MP2. It was also possible to see a constant evolution on the quantity of proanthocyanidins with time, with a slower decrease on MP3 when compared with the evolution of T and MP2 experiments. In Fig. $2 \mathrm{f}$ it was possible to observe the overall mDP of the three experiments. The evolution of T and MP2 samples was more constant, decreasing with time, though the $\mathrm{T}$ wine had at the end a smaller mDP than MP2. Concerning the MP3 wines, there 

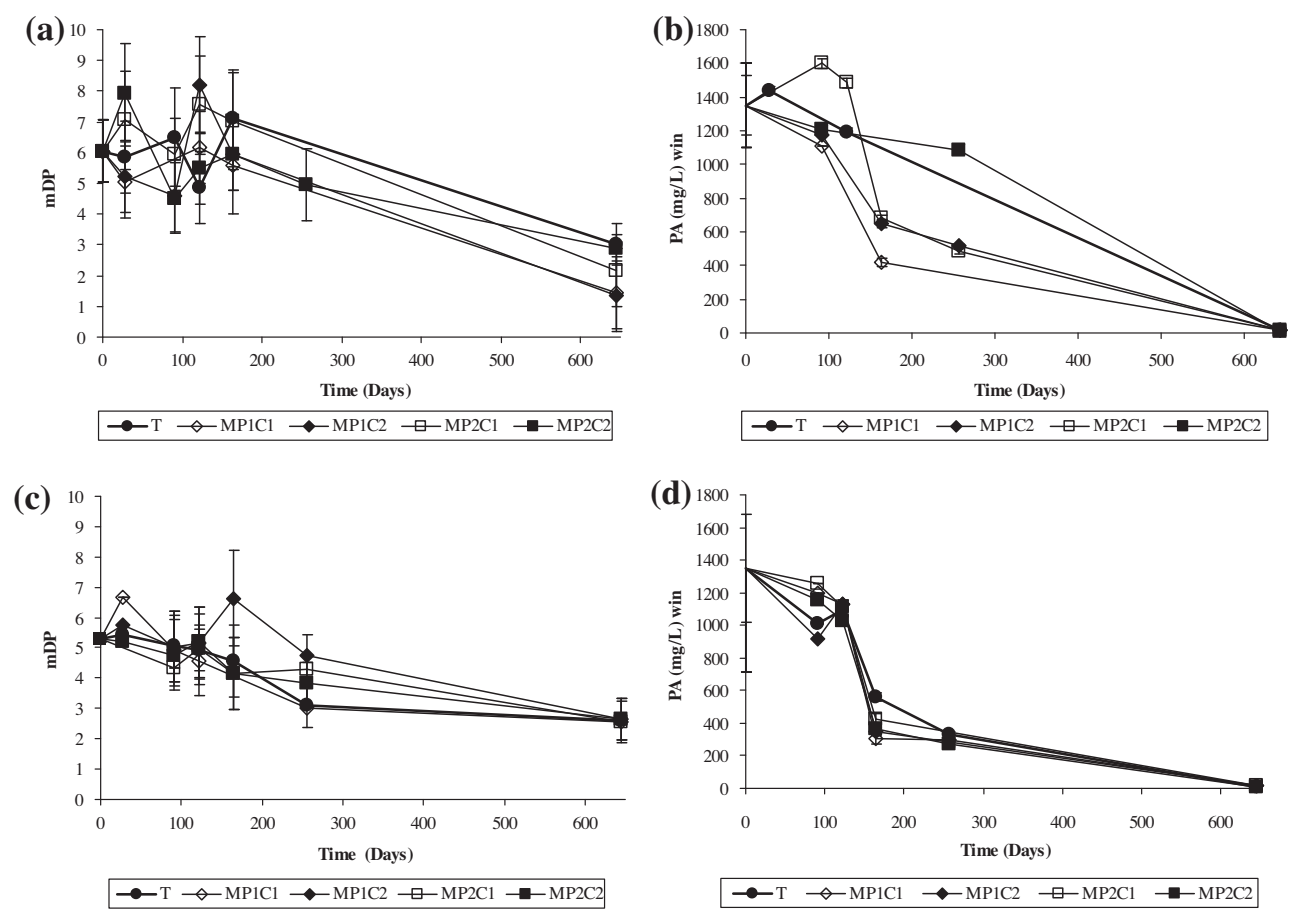

Fig. 3. Wine A (a) mDP for and (b) proanthocyanidins content (PA); wine B (c) mDP for, and (d) proanthocyanidins content (PA).

Table 2

Structural characteristics of the proanthocyanidins of wine C.

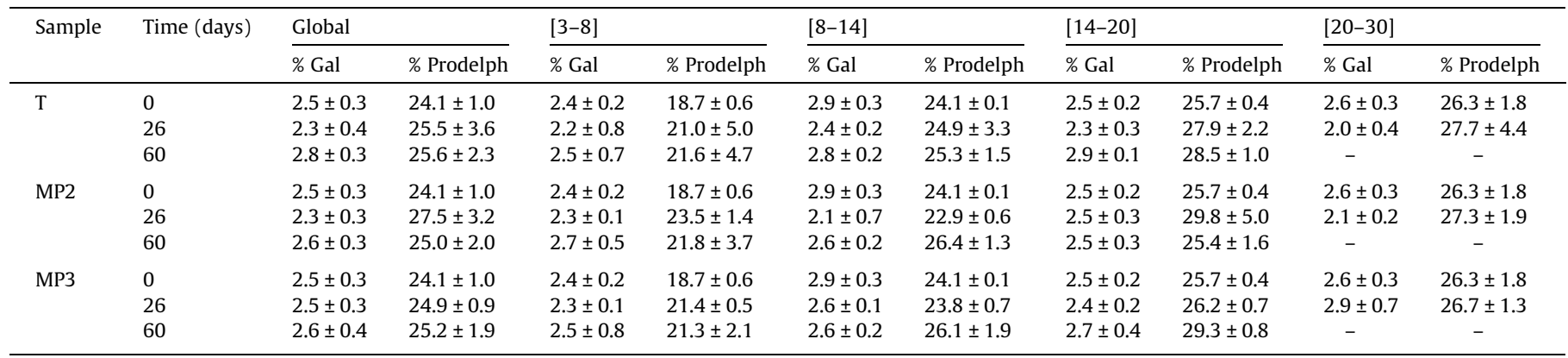

\% Gal - percentage of galloylation, \% prodelph - percentage of prodelphinidins. T is the wine with no addition of commercial mannoproteins; MP2 and MP3 are commercial yeast mannoproteins. Global, [3-8], [8-14], [14-20] and [20-30] are ranges of mean polymerisation degrees.

was a slight increase of the $\mathrm{mDP}$ at the beginning of the experiment, and subsequently a more evident decrease to lower values when compared with the other two wines.

Fig. 4 shows the quantity of proanthocyanidins per mDP interval and by day of sampling for each experiment. It is important to notice that the mDP values obtained for each of the eight purified fractions varied between 3.61 and 32.06 (data not shown), resulting in a very large range of values for this parameter. The highest weighted average $\mathrm{mDP}$ found in the three wine experiments was 16.97. Sun et al. (1998) and Maury, Sarni-Manchado, Lefebvre, Cheynier, and Moutounet (2001) have found values of $\mathrm{mDP}$ on wines of 22.1 and 27 , respectively. The fact that these long chain tannins remain in solution is probably due to: (a) stabilisation resulting from the complexation between polymeric tannins and anthocyanins, maintaining tannins soluble even with high mDP values as suggested by Maury et al. (2001); (b) eventually this stabilisation can result from the interaction between the condensed tannins and other wine macromolecules. Because of this variation of values among the eight tannin fractions obtained on the glass powder separation column we decided to show the results in intervals of mDP values, from 3 to 8,8 to 14,14 to 20 and 20 to 30 in order to facilitate the results evaluation. For the T sample (Fig. 4a), on day 0, the quantity of PA was similar to all groups of mDP. On day 26, there were proanthocyanidins of all mDP intervals, but in higher amounts on [3-8] and [8-14] mDP, decreasing on the other two intervals. On day 61, there were no proanthocyanidins with $\mathrm{MDP}$ [20-30], existing mainly on [3-8] and [14-20]. Concerning the MP2 added samples (Fig. 4b), the evolution of proanthocyanidins on day 26 was similar to day 0 , except for the fact that the quantity of proanthocyanidins decreases for the [8-14] mDP interval. On day 61, there was a prevalence of proanthocyanidins with mDP between 14 and 20, followed by [8-14] and finally [3-8], with no proanthocyanidins on the [20-30] interval. Regarding samples T and MP2, it seemed that there was no stabilisation effect but a continuous evolution of the polymerisation reactions, and precipitation of the polymers with the biggest chains and highest molecular weight. The MP3 added samples presented a smaller quantity of proanthocyanidins with mDP between 8 and 14 when comparing it with the other samples on day 26 (Fig. 4c). On day 61, most of the proanthocyanidins had an mDP on the interval [8-14], followed by the intervals [3-8] and [14-20]. At the end of the experiment it seemed that there was a stabilisation of the proanthocyanidins chains with $\mathrm{mDP}$ between 

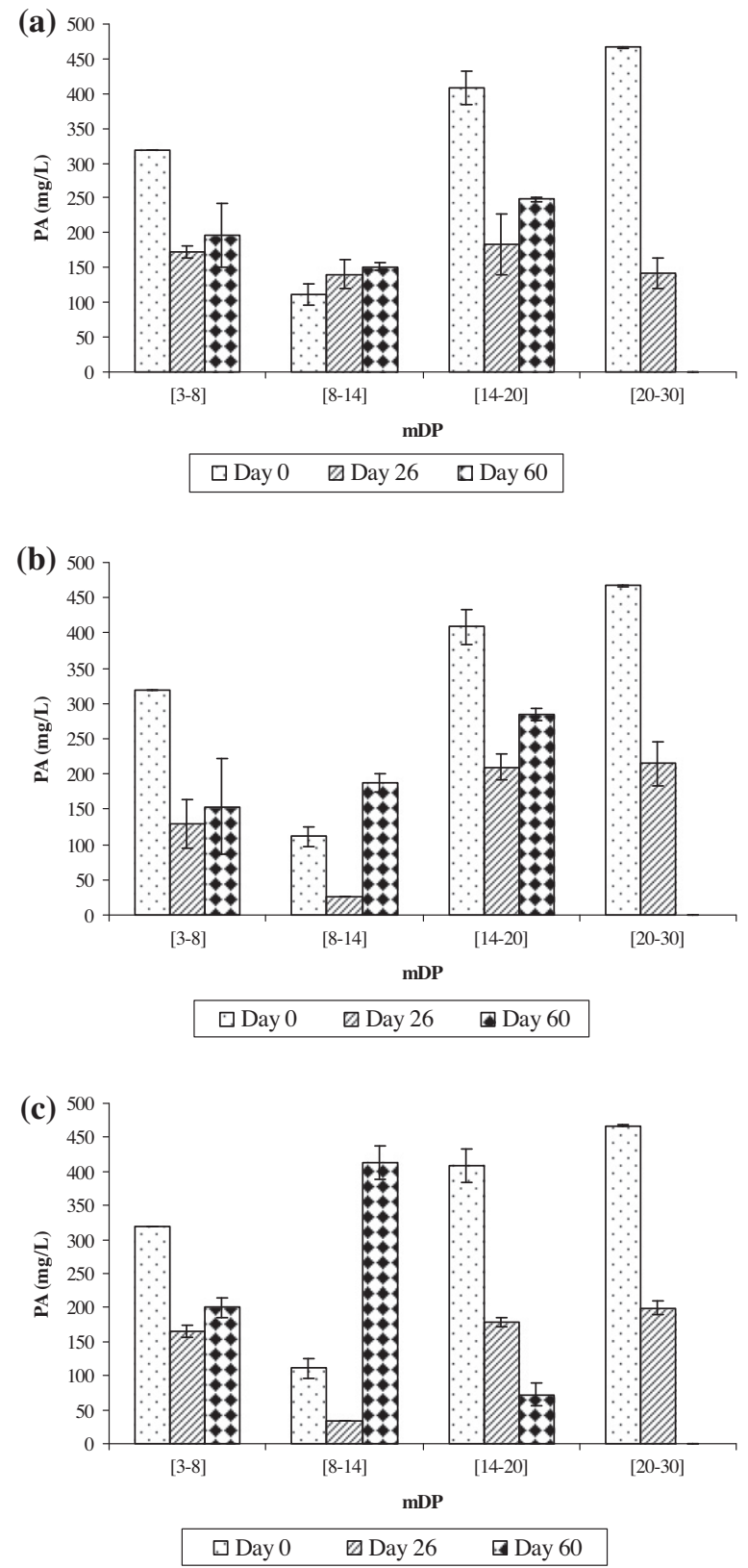

Fig. 4. Evolution of the quantity of proanthocyanidins per mDP interval and by day of sampling for wine C, (a) with no commercial mannoproteins addition, (b) with MP2 commercial mannoprotein addition, and (c) with MP3 commercial mannoprotein addition.

8 and 14, as most of the proanthocyanidins appeared with $\mathrm{mDP}$ in this interval, contrary to T and MP2. In fact, on T and MP2 samples, there was an evidence of a continuous evolution of the chain length until precipitation, with no stabilizing effect at all. Riou et al. (2002) verified that in a wine model solution, polysaccharides, namely mannoproteins, interfered with the particle size of proanthocyanidins, although they did not protect the tannins initial aggregation. Escot et al. (2001) and Guadalupe et al. (2007) demonstrated that mannoproteins addition alter significantly the mouth and structural properties of red wines, leading to a decrease in red wine astringency. If mannoproteins prevent tannin particle growth after the particle size reaches a certain number of monomers, then it is possible to explain why mannoproteins can contribute to tannin stabilisation and the achievement of a more rounded wine with less astringent tannins. The explanation for these properties can be explained not only by a precipitation of long chain tannins at the beginning of ageing, but also by this interaction between mannoproteins and tannins leading to the maintenance of the polymers in solution, preventing their growth and possibly their interaction with saliva proteins.

Though there was no evidence of a stabilizing effect of MP2 on tannins, it could be that there was a smaller interaction due to the characteristics of the commercial product itself that could act at a smaller scale than MP3. The molecular weight profile of MP3 commercial product, after purification on concanavalin-A, presented two polysaccharides with average molecular weights of 44 and $19 \mathrm{kDa}$. Comparing with the MP2 product, there were also two polysaccharides with average molecular weight of 164 and $8 \mathrm{kDa}$. This difference in polysaccharide composition could be the reason why the MP3 commercial product showed a stabilisation effect on tannin growth and MP2 had the same behaviour with the T samples (with no commercial mannoprotein addition). Poncet-Legrand et al. (2007) have shown that low molecular weight mannoproteins have stabilising effects on the grape seed tannin aggregation, and that high molecular weight molecules do not have any impact, suggesting that the stabilisation mechanism can be a steric stabilisation, explaining why the medium and low molecular weight molecules were more efficient.

The fact that for all modalities at day 61 there were no proanthocyanidins with a mDP higher than 20 was probably due to the conjugation of three hypotheses: (a) the polymerisation of flavan-3-ol units results in the formation of high molecular weight polymers that precipitate; (b) the association between tannins and anthocyanins as $\mathrm{T}-\mathrm{A}^{+}$complexes promotes the stability of the molecule without any further growth (Vidal Cartalade, Souquet, Fulcrand \& Cheynier, 2002); (c) as tannin tends to aggregate through time and further to precipitate, this leads to a reduction of the number of flavan-3-ol units existing in the solution, limiting the reaction between monomers and monomers with oligomers in order to form higher chain polymers.

\section{Conclusions}

The enriched mannoprotein commercial preparations did not have an effect on colour stabilisation of the studied wines. The evolution of colour parameters with time was similar for all experiments, showing no efficient effect of the three commercial products on the colour stability parameters of the wines. The global tannin profile evolution did not show significant differences. When it came to analysing the intervals of the several tannin polymerisation degrees it was possible to see differences between one of the commercial mannoproteins studied and the non-added mannoproteins experiment. MP3 seemed to stabilise the growth of tannins with a polymerisation degree between 8 and 14, suggesting that the interaction between mannoproteins and tannins leads to the maintenance of the tannins with an $\mathrm{mDP}$ in this interval in wine. The fact that the two concanavalin-A purified polysaccharides presented low molecular weights (44 and $19 \mathrm{kDa}$ ) supports the hypothesis of an interaction occurring between lowmedium MW mannoproteins and proanthocyanidins. Although there was no influence on the colour parameters, it is possible that specifically the commercial mannoprotein MP3 used in this work has some influence on the wine tannin aggregation evolution, contributing to the delay of tannin polymerisation in red wines. This study demonstrated the importance of studying not only the wine global mDP evolution but also the several existing polymerisation degrees, as there were significant differences between the modalities when it comes to a more detailed study. Further studies should be made with this commercial product, namely its interaction in wine model solutions in order to better understand the mechanisms of this interaction. The results of this work can be 
applied directly to the winery process with the aim of applying commercial mannoprotein enriched products to red wines for tannin stabilisation.

\section{Acknowledgements}

The authors would like to thank to Fundação para a Ciência e Tecnologia for the A. Rodrigues PhD Grant (SFRH/BDE/15598/ 2006) and to the company Ecofiltra (Portugal) for supplying the commercial preparations containing mannoproteins used in this study.

\section{References}

Albersheim, P., Nevis, D. J., English, P. D., \& Karr, A. (1967). A method for the analysis of sugars in plant cell-wall polysaccharides by gas liquid chromatography. Carbohydrate Research, 5, 340-345.

Baptista, A. S., Horii, J., Calori-Domingues, M. A., Micotti da Glória, E., Salgado, J. M., \& Vizioli, M. R. (2004). The capacity of manno-oligosaccharides, thermolysed yeast and active yeast to attenuate aflatoxicosis. World Journal of Microbiology and Biotechnology, 20, 475-481.

Chalier, P., Angot, B., Delteil, D., Doco, T., \& Gunata, Z. (2007). Interactions between aroma compounds and whole mannoprotein isolated from Saccharomyces cerevisiae strains. Food Chemistry, 100, 22-30.

Dallas, C., Ricardo da Silva, J. M., \& Laureano, O. (1996). Products formed in model wine solutions involving anthocyanins, procyanidin B2, and acetaldehyde. Journal of Agriculture Food Chemistry, 44, 2402-2407.

Doco, T., Vuchot, P., Cheynier, V., \& Moutounet, M. (2003). Structural modification of wine arabinogalactans during aging on lees. American Journal of Enology and Viticulture, 54(3), 150-157.

Dubois, M., Gilles, K. A., Hamilton, J. K., Rebers, P. A., \& Smith, S. (1956). Colourimetric method for determination of sugars and related substances. Analytical Chemistry, 28, 350-356.

Escot, S., Feulliat, M., Dulau, L., \& Charpentier, C. (2001). Release of polysaccharides by yeasts and the influence of released polysaccharides on colour stability and wine astringency. Australian Journal of Grape and Wine Research, 7, 153-159.

Feuillat, M. (2003). Yeast macromolecules: Origin, composition and enological interest. American Journal of Enology and Viticulture, 54, 211-213.

Fulcrand, H., Remy, S., Souquet, J.-M., Cheynier, V., \& Moutounet, M. (1999). Study of wine tannin oligomers by on-line liquid chromatography electrospray ionization mass spectrometry. Journal of Agricultural and Food Chemistry, 47, 1023-1028.

Gonçalves, F., Heyraud, A., Pinho, M. N., \& Rinaudo, M. (2002). Characterization of white wine mannoproteins. Journal of Agricultural and Food Chemistry, 50, 6097-6101.

Guadalupe, Z., \& Ayestarán, B. (2008). Effect of commercial mannoprotein addition on polysaccharide, polyphenolic, and colour composition in red wines. Journal of Agricultural and Food Chemistry, 56, 9022-9029.

Guadalupe, Z., Martínez, L., \& Ayestarán, B. (2010). Yeast mannoproteins in red winemaking. Effect on polysaccharide, polyphenolic and colour composition. American Journal of Enology and Viticulture, 61, 191-200.

Guadalupe, Z., Palacios, A., \& Ayestarán, B. (2007). Maceration enzymes and mannoproteins: A possible strategy to increase colloidal stability and colour extraction in red wines. Journal of Agricultural and Food Chemistry, 55, 4854-4862.

Guilloux-Benatier, M., Guerreau, J., \& Feuillat, M. (1995). Influence of initial colloid content on yeast macromolecule production and on the metabolism of wine microorganisms. American Journal of Enology and Viticulture, 46, 486-492.
Haslam, E. (1980). In vino veritas: Oligomeric procyanidins and the ageing of red wines. Phytochemistry, 19, 2577-2582.

IV, O. (2006). Recueil des Méthodes Internationales d'Analyse des Vins et Moûts. Paris: Organisation International de la Vigne et du Vin.

Klis, F. M., Mol, P., Hellingwerf, K., \& Brul, S. (2002). Dynamics of cell wall structure in Saccharomyces cerevisiae. FEMS Microbiology Reviews, 26, 239-256.

Labarbe, B., Cheynier, V., Brossaud, F., Souquet, J. M., \& Moutounet, M. (1999). Quantitative fractionation of grape proanthocyanidins according to their degree of polymerization. Journal of Agricultural and Food Chemistry, 47, 2719-2723.

Lowry, O. H., Roserbrough, N. J., Farr, A. L., \& Randall, R. J. (1951). Protein measurement with the Folin phenol reagent. Journal of Biological Chemistry, 193 265-275.

Maury, C., Sarni-Manchado, P., Lefebvre, S., Cheynier, V., \& Moutounet, M. (2001). Influence of fining with different molecular weight gelatins on proanthocyanidin composition and perception of wines. American Journal of Enology and Viticulture, 52, 140-145.

Moine-Ledoux, V., \& Dubourdieu, D. (2002). Rôle des mannoprotéines de levures vis-à-vis de la stabilisation tartrique des vins. Bulletin de l'O.I.V., 75(857/858) 471-482.

Moine-Ledoux, V., Perrin, A., Paladin, I., \& Dubourdieu, D. (1997). Premiers Résultats de Stabilisation Tartrique des Vins par Addition de Mannoprotéines Purifiées (Mannostab). Journal International des Sciences de la Vigne et du Vin, 31, 23-31.

Monagas, M., Gómez-Cordovés, C., Bartolomé, B., Laureano, O., \& Ricardo-da-Silva, J. M. (2003). Monomeric, oligomeric, and polymeric flavan-3-ol composition of wines and grapes from Vitis vinifera L. cv. Graciano, Tempranillo, and Cabernet Sauvignon. Journal of Agricultural and Food Chemistry, 51, 6475-6481.

Nunez, Y., Carrascosa, A., González, R., Polo, M., \& Martinez-Rodriguez, A. (2006) Isolation and characterization of a thermally extracted yeast cell wall fraction potentially useful for improving the foaming properties of sparkling wines. Journal of Agricultural and Food Chemistry, 54, 7898-7903.

Poncet-Legrand, C., Doco, T., Williams, P., \& Vernhet, A. (2007). Inhibition of grape seed tannin aggregation by wine mannoproteins: Effect of polysaccharide molecular weight. American Journal of Enology and Viticulture, 58, 87-91.

Ricardo da Silva, J. M., Rosec, J. P., Bourzeix, M., \& Heredia, N. (1990). Separation and quantitative determination of grape and wine procyanidins by high performance reversed phase liquid chromatography. Journal of the Science of Food and Agriculture, 53, 85-92.

Rigaud, J., Perez-Ilzarbe, J., Ricardo da Silva, J. M., \& Cheynier, V. (1991). Micro method for the identification of proanthocyanidin using thiolysis monitored by high-performance liquid chromatography. Journal of Chromatography, 540, 401-405.

Riou, V., Vernhet, A., Doco, T., \& Moutounet, M. (2002). Aggregation of grape seed tannins in model wine-effect of wine polysaccharides. Food Hydrocolloids, 16, 17-23.

Saulnier, L., Mercereau, T., \& Vezinhet, F. (1991). Mannoproteins from flocculating and non-flocculating Saccharomyces cerevisiae yeasts. Journal of the Science of Food and Agriculture, 54, 275-286.

Somers, T. C. (1971). The polymeric nature of wine pigments. Phytochemistry, 10, 2175-2186.

Somers, T. C., \& Evans, M. E. (1977). Spectral evaluation of young red wines: Anthocyanin equilibria, total phenolics, free and molecular $\mathrm{SO}_{2}$, "chemical age". Journal of the Science of Food and Agriculture, 28, 279-287.

Sun, B., Leandro, C., Ricardo da Silva, J. M., \& Spranger, I. (1998). Separation of grape and wine proanthocyanidins according to their degree of polymerization. Journal of Agricultural and Food Chemistry, 46, 1390-1396.

Vasserot, Y., Caillet, S., \& Maujean, A. (1997). Study of anthocyanin adsorption by yeast lees. Effect of some physicochemical parameters. American Journal of Enology and Viticulture, 48, 433-437.

Vidal, S., Cartalade, D., Souquet, J.-M., Fulcrand, H., \& Cheynier, V. (2002). Changes in proanthocyanidin chain length in wine like model solutions. Journal of Agricultural and Food Chemistry, 50, 2261-2266.

Waters, E., Pellerin, P., \& Brillouet, J. (1994). A Saccharomyces mannoprotein that protects wine from protein haze. Carbohydrate Polymers, 23, 185-191. 